\title{
Pathogenic Diversity of Phytophthora sojae in Ohio Soybean Fields
}

\author{
A. E. Dorrance, Assistant Professor, S. A. McClure, Research Assistant, and A. deSilva, Former Postdoctoral Re- \\ search Associate, Department of Plant Pathology, The Ohio State University, OARDC, Wooster 44691-4096
}

\begin{abstract}
Dorrance, A. E., McClure, S. A., and deSilva, A. 2003. Pathogenic diversity of Phytophthora sojae in Ohio soybean fields. Plant Dis. 87:139-146.

Problems with early season soybean stand establishment, and an increase in incidence of Phytophthora root and stem rot caused by Phytophthora sojae, prompted a reassessment of the pathogen population in Ohio. Earlier studies had indicated a potential for pathogen adaptation to commonly deployed Rps genes in soybeans. Fifty-seven fields, part of an earlier study in 1990 and 1991, along with 29 additional fields were sampled in either 1997 or 1999. Two soybean cultivars, Sloan (rps) and Resnik (Rps $1 \mathrm{k}$ ), were used as bait in a seedling bioassay to isolate $P$. sojae from the soil samples. P. sojae was recovered from 82 of the 86 fields sampled. Of the 429 isolates recovered from these soils, 325 and 104 were baited with soybean cultivars Sloan and Resnik, respectively. The $P$. sojae population in Ohio increased in the number of pathotypes (races) as well as in complexity since the earlier surveys. There were 72 and 202 pathotypes identified on 8 and 13 Rps gene differentials, respectively, in the current study. When the data were compared by location, $96,65,73,78,51$, and $52 \%$ of the locations had at least one isolate with virulences to Rps $1 \mathrm{a}, R p s 1 \mathrm{~b}, R p s 1 \mathrm{c}, R p s 1 \mathrm{k}, R p s 3 \mathrm{a}$, and $R p s 6$, respectively. The mean complexity, the number of susceptible interactions on 8 differentials, increased from 3.01 to 4.06 between 1991 and 1997/1999. In addition, the pathogenic diversity as measured by the Shannon index increased from 2.71 to 3.28 for isolates recovered from the 57 fields sampled in both surveys. Producers whose fields were sampled were surveyed to determine if changes in the $P$. sojae population could be linked with production practices. There was a significant association between $(P \leq 0.05)$ reduced tillage practices and the presence of isolates that had virulence to Rps 1 k; reduced tillage fields also had isolates with virulence to a greater number of differentials. Due to the percentage of isolates that have virulence to many of the Rps genes, it is questionable how long a single Rps gene or several stacked Rps genes will remain viable disease management tools for $P$. sojae, unless a novel Rps gene is identified.
\end{abstract}

Additional keywords: binary code, HaGiS, octal nomenclature, virulence analysis

Soybean (Glycine max (L.) Merr.) production in Ohio has expanded dramatically in the past few years, with the majority of the production area located on the western side of the state. Soil textures in this region range from silty clay loam to clay loam, with clay content as high as $60 \%$ in some fields. These heavy soil types, when moisture is present, provide an environment conducive to sporulation of and infection by the soybean pathogen Phytophthora sojae M.J. Kaufmann \& J.W. Gerdemann.

$P$. sojae-induced preemergence damping-off, and root and stem rot have been managed mainly by deploying single dominantly inherited resistance genes (Rps) in commercial soybean cultivars. $P$. sojae interacts with soybeans in a gene-forgene manner (8), and as in other hostpathogen systems, populations have adapted to Rps genes as they were de-

Corresponding author: A. E. Dorrance

E-mail: dorrance.1@osu.edu

Accepted for publication 25 September 2002.

Publication no. D-2002-1126-01R

(C) 2003 The American Phytopathological Society ployed (28). Changes in virulence composition (compatible or susceptible interaction with a plant containing a specific resistance gene) were documented in the $P$. sojae population in Ohio from 1980 to 1990 in an earlier study by Schmitthenner et al. (29). From soil and plant samples collected from 1978 to 1980 , they reported that the majority of isolates were classified as $P$. sojae race 7 (virulence for $R p s$ 1a, 3a, $7)$, race 9 (1a, 6, 7), and race 3 (1a, 7). In 1990 , the majority of isolates were classified as $P$. sojae races 3, 7, 4 (1a, 1c, 7), and 1 (7). During 1991, P. sojae races 3, 7, and 9 were the most common, but 18 new races, all of which could cause disease on cultivars with Rps $1 \mathrm{k}$, also were identified (29). This increasing number of races and adaptation to Rps genes is not unique to Ohio; similar findings have recently been reported from Indiana (1), Illinois (22), Iowa (37), Michigan (18), and Minnesota (21) as well as Australia (27).

From the earlier surveys, Schmitthenner et al. (29) concluded that $P$. sojae was a highly variable pathogen with regards to virulence phenotype. They proposed that Phytophthora root rot levels on soybean cultivars with the Rps1k gene would increase within a few years, provided that these new races were competitive with the rest of the $P$. sojae population in any given field. The challenge for pathologists is to be able to detect when virulence to specific resistance genes within the pathogen population has increased to levels in which single gene deployment is no longer effective economically, and to determine where on a regional level these changes have occurred. For foliar and stem pathogens, this may be readily seen by aboveground symptoms. For soilborne pathogens, assessing changes in virulence is a much more laborious process. Soil baiting has been used to exploit the pathogenicity of Phytophthora species in the past for isolation and identification prior to the use of antibiotics in selective media (reviewed in Erwin and Ribeiro, 7). This laboratory has used both soybean leaf disks and seedlings for a number of years to bait $P$. sojae $(4,29)$. In the previous surveys, only a few soil samples were collected from each field for isolation of $P$. sojae. However, the level of diversity that may exist in a given field and when a change in cultivar selection is warranted have not been evaluated.

In the last survey (1990 and 1991), a soybean cultivar Amcor89 (USDA Accession PI 546375) with the Rps $1 \mathrm{k}$ gene was used as a seedling bait in addition to Sloan (USDA Accession PI 548616), which has no Rps genes. The majority of isolates that were recovered from the Amcor89 seedlings did not have a susceptible interaction with the Rps $1 \mathrm{k}$ differential when subsequently tested with the hypocotyl inoculation technique $(14,29)$. Amcor89 has very low levels of partial resistance (race nonspecific resistance) and thus is highly susceptible to some races of $P$. sojae, which may explain in part this discrepancy. Soil baiting with a soybean cultivar with a higher level of partial resistance may select for those isolates that are more aggressive and thus maintain virulence on the selected Rps gene.

Crop rotation, soil drainage, and tillage practices can all influence the soil environment in ways that may promote disease development (28). Anderson (2) demonstrated that severe disease and yield loss can develop in soybean cultivars with partial resistance when they are grown in a continuous soybean production system. Increased soil drainage and some forms of tillage have been shown to limit the amount of yield loss due to Phytophthora root and stem rot (30). Within the north central region of the United States, recent economic factors have indirectly promoted 
repeated planting of soybeans in the same fields. In addition, a large proportion of Ohio's production fields are under reduced tillage systems. The role these management factors play in population shifts of soilborne pathogens is unknown.

Races of $P$. sojae have been designated in the order that they have been discovered based on inoculation of differentials. Fiftyfive races of $P$. sojae have now been described $(1,9,14,15,22,23,25,27,29,31-33,38)$. However, the differentials used in these race designations have not always been the same. The most commonly used differentials contain the following Rps genes: $R p s 1 \mathrm{a}, R p s 1 \mathrm{~b}, R p s 1 \mathrm{c}, R p s 1 \mathrm{~d}, R p s 1 \mathrm{k}, R p s 6$, and Rps7. Recently, Ryley et al. (27) and Leitz et al. (23) added additional soybean differentials with resistance genes Rps $3 \mathrm{~b}$, Rps3c, Rps4, and Rps5. The resistance gene Rps 2 has not been used often as a differential. The resistant reaction on plants with Rps 2 is an intermediate hypocotyl reaction in which only half of the seedlings die or a long, slowly expanding lesion forms at the inoculation site (20). As breeders begin to incorporate new resistance genes into commercial soybean cultivars, the interaction of $P$. sojae with these additional resistance genes has become increasingly important.

Race nomenclature for $P$. sojae has become increasingly cumbersome. Increasing pathotype diversity or number of races has become a problem both in the reporting in scientific papers and in discussing these changes with extension clientele. The number of races possible on 8 differentials $\left(2^{\mathrm{N}}\right.$ where $\mathrm{N}=$ number of differentials $)$ is 256 or 8,192 on all 13 differentials. An octal system is another type of nomenclature whereby differentials are grouped in sets of three with a single digit designating the host-pathogen interaction on all of the differentials in the set (10). This type of nomenclature has been used for Phytophthora infestans (12) and Rhynchosporium secalis (11). We have used an octal nomenclature in this study because it allows for comparisons and analysis of com- plex pathotype population data among populations and comparisons between studies. Summaries of these analyses can then be used to provide disease management guidelines for producers, agronomists, and breeders.

Based on the prediction that widespread losses to $P$. sojae could occur in Ohio, the state was surveyed during 1997 and 1999 to assess the $P$. sojae population. The objectives of this study were: (i) to determine if changes in pathotypes had occurred since the previous survey; (ii) to determine if the level of pathogenic diversity within a field was similar to the level of diversity in a region; (iii) to determine if soil baiting using seedlings with specific Rps genes could be used to detect population shifts; and (iv) to determine if changes in pathotype and inoculum density could be linked with soybean production practices.

\section{MATERIALS AND METHODS}

Statewide sample collection and isolation. At six sites per field, two soil cores (10 $\mathrm{cm}$ diameter by $15 \mathrm{~cm}$ deep) were collected from fields in northwestern Ohio during 1997 and 1999. These fields were the same locations for 57 of the 65 fields in northwestern Ohio previously sampled (29). In addition, 29 fields with reports of losses due to $P$. sojae from seed company agronomists and crop consultants from north, western, and southwestern Ohio were also sampled, for a total of 86 fields. All of the soil samples were processed as previously described (29). For this study, the soybean seedling bioassay method was the only technique used to bait for $P$. sojae (29). Each soil sample was dispensed into two pots; one pot was planted with the soybean cultivar Sloan (rps) and the other pot was planted with the cultivar Resnik (Rps1k; USDA Accession PI 534645) as bait. Two weeks after planting, $P$. sojae was isolated from seedlings with expanding brown lesions on the hypocotyl and roots, on PIBNC selective medium (29) and stored at $4{ }^{\circ} \mathrm{C}$ until evaluated.
Intensive sampling. Two fields were selected to determine if the level of diversity within a field was similar to that of the region. One field located in Wood County was part of the survey, and preliminary data indicated the presence of isolates with virulence to Rps $1 \mathrm{k}$. The second field, located in Sandusky County, which was not part of the statewide survey, has had replant problems in two of the three previous years with soybean cultivars with Rps1c. One hundred soil samples from each field were collected during 2000. Single soil cores, as described above, were collected $30 \mathrm{~m}$ apart on a $10 \times 10$ grid for a total sample area of approximately $90,000 \mathrm{~m}^{2}$. These soils were assayed as above, but hymexazole (Sigma Chemical Co., St. Louis, MO) was added to the selective medium at $20 \mathrm{mg} /$ liter to limit the growth of Pythium spp. Hymexazole at $50 \mathrm{mg} / \mathrm{liter}$ was reported previously to limit growth of P. sojae (17).

Pathotype evaluation of cultures. All isolates were examined for oospore and sporangia size and shape, as well as appearance of growth on potato dextrose agar (PDA), to verify that the isolate was $P$. sojae. P. sojae does not grow on PDA, whereas Pythium spp. and other Phytophthora spp. grow profusely (19). The pathotypes of the isolates were determined using the hypocotyl inoculation technique $(14,28)$ on the following differentials: 'Williams' (universal suscept), 'Harlon' (Rps1a), 'Harosoy 13XX' (Rps1b), 'Williams79' (Rps1c), PI103091 (Rps1d), 'Williams82' (Rps1k), L76-1988 (Rps2), L83570 (Rps3), PRX146-36 (Rps3b), PRX14548 (Rps3c), L85-2352 (Rps4), L85-3059 (Rps5), 'Harosoy62XX' (Rps6), and 'Harosoy' (Rps7). The differentials were grown in the field and maintained at The Ohio State University. Using the hypocotyl inoculation method $(14,28), 0$ to 2 dead seedlings out of 8 indicated a resistant response, and 3 to 8 dead seedlings indicated intermediate and susceptible responses. For $R p s 2$, a susceptible interaction was designated only when all 8 seedlings were killed

Table 1. Reverse/binary and octal codes for common races of Phytophthora sojae

\begin{tabular}{|c|c|c|c|c|c|c|c|c|c|c|c|c|c|c|}
\hline \multicolumn{13}{|c|}{ Soybean differentials with $R p s$ alleles ${ }^{\mathrm{a}}$} & \multirow[b]{2}{*}{ Octal } & \multirow{2}{*}{$\begin{array}{r}\text { P. soja } \\
\text { race }^{\mathrm{b}}\end{array}$} \\
\hline $1 \mathbf{a}$ & 1b & 1c & 1d & $1 \mathbf{k}$ & 2 & 3a & $\mathbf{3 b}$ & $3 \mathbf{c}$ & 4 & 5 & 6 & 7 & & \\
\hline 0 & 0 & 0 & 0 & 0 & 0 & 0 & 0 & 0 & 0 & 0 & 0 & 1 & 00001 & 1 \\
\hline 1 & 0 & 1 & 0 & 0 & 0 & 0 & 0 & 0 & 0 & 0 & 0 & 1 & 50001 & 4 \\
\hline 1 & 0 & 0 & 0 & 0 & 0 & 1 & 0 & 0 & 0 & 0 & 0 & 1 & 10101 & 7 \\
\hline 1 & 1 & 1 & 0 & 1 & 0 & 0 & 0 & 0 & 0 & 0 & 0 & 1 & 72001 & 25 \\
\hline 1 & 0 & 0 & 0 & 0 & 0 & 0 & 0 & 0 & 0 & 0 & 0 & 1 & 10001 & 3 \\
\hline 1 & 1 & 0 & 0 & 1 & 0 & 0 & 0 & 0 & 0 & 0 & 0 & 1 & 32001 & 28 \\
\hline 1 & 1 & 1 & 0 & 1 & 1 & 0 & 0 & 0 & 0 & 1 & 0 & 1 & 76021 & $25^{*}$ \\
\hline 1 & 1 & 0 & 0 & 1 & 1 & 0 & 0 & 0 & 0 & 0 & 0 & 1 & 36001 & $28^{*}$ \\
\hline
\end{tabular}

a 0 indicates an incompatible reaction, and 1 indicates a compatible reaction on the differentials following inoculation. Octal digits were assigned as follows: $000=0,100=1,010=2,001=4,110=3,101=5,011=6$, and $111=7$. The octal digits in this system are sorted according to the number of virulences per triplet (16).

${ }^{\mathrm{b}}$ P. sojae race designations are based on the response following inoculation on eight differentials: Williams (universal suscept), Harlon (Rps1a), Harosoy 13XX (Rps1b), Williams 79 (Rps1c), PI103091 (Rps1d), Williams 82 (Rps1k), L83-570 (Rps3), Harosoy 62XX (Rps6), and Harosoy (Rps7). * indicates a susceptible interaction with one or more of the differentials L76-1988 (Rps2), PRX 146-36 (Rps3b), PRX 145-48 (Rps3c), L85-2352 (Rps4), or L853059 (Rps5) 
to eliminate possible false positives associated with the intermediate resistant reaction on this differential (20).

Pathotype evaluation. An octal nomenclature was utilized in this study for an efficient, convenient method to summarize this data $(11,12)$. The spreadsheet program "HaGiS," developed by Herrman et al. (16), was used to convert virulence data to an octal format and to analyze the data to produce frequency distributions of virulence to specific Rps genes, to isolate complexities (the number of differentials with which an isolate has a susceptible interaction), and to calculate a number of diversity indices. Gilmour (10) had originally described the race codes based on arranging the differentials from right to left. The spreadsheet developed by Herrman et al. (16) arranges the differentials in a reverse octal format similar to the system proposed by Goodwin et al. (12) for P. infestans. The advantages of this are that differentials could be added easily as new genes are discovered. In this system, differentials are arranged in groups of three, and each group of three differentials is coded as one octal digit. For this study, soybean differentials were grouped as follows: Rps1a, Rps 1b, and $R p s 1 \mathrm{c}$, the first digit; Rps $1 \mathrm{~d}, R p s 1 \mathrm{k}$, and Rps 2 , the second digit; Rps $3 \mathrm{a}, R p s 3 \mathrm{~b}$, and $R p s 3 \mathrm{c}$, the third digit; Rps $4, R p s 5$, and Rps6, the fourth digit; and Rps7, the fifth digit. Octal numbers were assigned based on the compatible or incompatible interaction for each differential within a set. In this spreadsheet (16), 0 indicates an incompatible reaction and 1 indicates a compatible reaction. Octal digits were assigned as follows: $000=0 ; 100=1 ; 010=2 ; 001$ $=4 ; 110=3 ; 101=5 ; 011=6$; and $111=$ 7. Table 1 illustrates the octal code for the most common races of $P$. sojae. Pathogenic diversity was quantified with the Shannon index for the number of phenotypes as calculated by the HaGiS Habgood spreadsheet program (16).

Management practices. The effect of management practices on population change was evaluated by requesting the following information from each of the producers where soil samples were taken: crop production history for the past 10 years including the soybean cultivar, soil type, spacing of drain tiles, and tillage practices. For each field, the number of isolates recovered, the number of differentials (for Rps 1a, Rps 1b, Rps1c, Rps 1d, $R p s 1 \mathrm{k}, R p s 3 \mathrm{a}, R p s 6$, and Rps7) with which the $P$. sojae population in that field had a susceptible interaction, and the presence of a susceptible interaction on the Rps 1k differential $(1=$ present, $0=$ absent $)$ were correlated with the number of years in the past five that soybeans were planted in the sampled field, drainage score, and tillage practice. The drainage score was determined by assessing a combination of soil type and distance between drain tiles and assigning a score of 1 to well drained, 2 to moderately drained, and 3 to poorly drained soils. For example, a field soil with greater than $50 \%$ clay content and distance between drainage tiles greater than $15 \mathrm{~m}$ was classified as poorly drained. The type of tillage that was used on a particular field was scored as $1=$ conventional tillage, $2=$ minimum tillage, and $3=$ no-till. As a preliminary step in determining potential associations between the pathogen population parameters (number of isolates, presence of Rps $1 \mathrm{k}$, and number of differentials with single Rps genes with which the population had a susceptible interaction) and crop production practices of rotation, tillage, and soil drainage characters as defined above, correlations were computed with PROC CORR of SAS (SAS Institute, Cary, NC). Because the correlation coefficient is not fully appropriate for quantifying relationships for data that are not continuously (and normally) distributed, the correlations were used as a first step in determining whether or not there were significant relationships between variables. When there was a significant correlation $(P$ $<0.05$ ), a generalized linear model (6) was fitted to the data to verify the relationship. PROC GENMOD of SAS was used for these latter analyses.

\section{RESULTS}

Statewide survey. In the statewide survey, $P$. sojae was recovered from 82 of the 86 fields sampled during 1997/1999. From 81 fields, 325 P. sojae isolates were baited with the soybean cultivar Sloan ( $r p s$, while $104 P$. sojae isolates were recovered from 48 fields with Resnik (Rps 1k) (Table 2). Following inoculation of hypocotyls, there were 72 and 202 different pathotypes (races) of $P$. sojae identified on 8 and 13 differentials, respectively. This was an increase of 34 pathotypes on 8 differentials over the previous survey during 1990. More than $50 \%$ of the isolates collected during the present survey had a susceptible interaction with the Rps differentials for Rps 1a, Rps1b, Rps1k, and Rps7 (Fig. 1A); whereas 47 and $32 \%$ had susceptible interactions with $R p s 1 \mathrm{c}$ and $R p s 3 \mathrm{a}$, respectively. These differentials represent the most commonly deployed Rps genes in commercial soybean cultivars in the north central region. When the data were compared by field, $96,65,73,78,51,52$, and

Table 2. Location and number of Phytophthora sojae isolates recovered via soil baiting with the soybean cultivars Resnik (Rps1k) or Sloan (rps) in Ohio during 1997 and 1999

\begin{tabular}{|c|c|c|c|c|c|c|c|}
\hline \multirow[b]{2}{*}{ County } & \multicolumn{2}{|c|}{ Combined } & \multicolumn{2}{|c|}{ Resnik bait } & \multicolumn{2}{|c|}{ Sloan bait } & \multirow[b]{2}{*}{ Total isolates } \\
\hline & Fields sampled & Fields with $P$. sojae & No. of fields ${ }^{a}$ & No. of isolates & No. of fields & No. of isolates & \\
\hline Adams & 2 & 2 & 2 & 2 & 2 & 6 & 8 \\
\hline Allen & 2 & 2 & 0 & 0 & 2 & 5 & 5 \\
\hline Auglaize & 1 & 1 & 1 & 4 & 1 & 4 & 8 \\
\hline Brown & 4 & 4 & 3 & 6 & 4 & 18 & 24 \\
\hline Clinton & 2 & 1 & 1 & 4 & 1 & 6 & 10 \\
\hline Crawford & 8 & 7 & 3 & 3 & 7 & 51 & 54 \\
\hline Darke & 6 & 6 & 2 & 2 & 6 & 24 & 26 \\
\hline Defiance & 8 & 8 & 6 & 18 & 8 & 26 & 44 \\
\hline Hancock & 6 & 5 & 2 & 2 & 5 & 23 & 25 \\
\hline Hardin & 6 & 5 & 2 & 5 & 5 & 15 & 20 \\
\hline Highland & 1 & 1 & 1 & 1 & 1 & 4 & 5 \\
\hline Huron & 1 & 1 & 1 & 1 & 1 & 1 & 2 \\
\hline Marion & 4 & 4 & 2 & 5 & 4 & 11 & 16 \\
\hline Ottawa & 5 & 5 & 3 & 6 & 5 & 8 & 14 \\
\hline Paulding & 4 & 4 & 3 & 7 & 4 & 13 & 20 \\
\hline Putnam & 2 & 2 & 2 & 2 & 2 & 6 & 8 \\
\hline Seneca & 6 & 6 & 1 & 1 & 6 & 40 & 41 \\
\hline VanWert & 8 & 8 & 6 & 14 & 8 & 29 & 43 \\
\hline Williams & 2 & 2 & 2 & 2 & 2 & 8 & 10 \\
\hline Wood & 5 & 5 & 3 & 8 & 4 & 15 & 23 \\
\hline Wyandot & 3 & 3 & 2 & 11 & 3 & 12 & 23 \\
\hline Total & 86 & 82 & 48 & 104 & 81 & 325 & 429 \\
\hline
\end{tabular}

${ }^{a}$ No. of fields indicates the number of fields that yielded an isolate with the soybean cultivar listed as bait. 
$100 \%$ of the fields had at least one isolate with virulence to $R p s 1 \mathrm{a}, R p s 1 \mathrm{~b}, R p s 1 \mathrm{c}$, Rps $1 \mathrm{k}$, Rps $3 \mathrm{a}$, Rps6, and Rps7. In addition, 47 of the 82 fields positive for $P$. sojae had isolates that had virulence to at least one 2or 3-Rps gene combination. Twenty-one percent of the isolates collected had a susceptible interaction with gene combination Rps 1a plus Rps3a. Rps gene combinations of Rps 1c plus Rps $3 \mathrm{a}$ and $R p s 1 \mathrm{k}$ plus $R p s 3 \mathrm{a}$ were vulnerable to 9.0 and $12.1 \%$ of the population, respectively (Fig. 1B).

Pathotypes/complexity. In the statewide survey, 62 of the 202 pathotypes as determined on the 13 differentials were identified more than one time. The most common pathotypes (Table 3) recovered were 00001 or race 1 (vir Rps 7); 72001 or race 25 (vir 1a, 1b, 1c, 1k, 7); 10001 or race 3 (vir $1 \mathrm{a}, 7$ ); 50001 or race 4 (vir 1a, 1c, 7); 32001 or race 28 (vir 1a, 1b, 1k, 7); 76021 (vir 1a, 1b, 1c, 1k, 5, 7); and 36001 (vir 1a, 1b, 1k, 2, 7). The total number of differentials or Rps genes with which an isolate has a susceptible interaction indi- cates complexity. In this study, the mean complexity of the isolates on the 13 differentials was 5.93 as calculated by the Habgood Spreadsheet program (16).

Baiting with Resnik (Rps1k) versus Sloan (rps). In the 1997/1999 survey, 104 of the 429 P. sojae isolates were recovered from the soybean cultivar Resnik, and 90 of the 104 had a compatible reaction on the Rps 1k soybean differential when tested with the hypocotyl inoculation technique. There were a total of 64 fields from which isolates were recovered that had a compatible interaction with the Rps $1 \mathrm{k}$ differential using both Sloan and Resnik as bait (Table 3). From 42 and 51 of these 64 fields, $P$. sojae isolates were recovered from soybean cultivar Resnik (Rps $1 \mathrm{k})$ and Sloan ( $r p s)$, respectively. However, in eight of the fields in which isolates with virulence to Rps $1 \mathrm{k}$ were only recovered from Sloan, only one or two isolates were recovered per field, indicating that $P$. sojae populations may be low in these fields. In contrast, 13 of the 64 fields had isolates
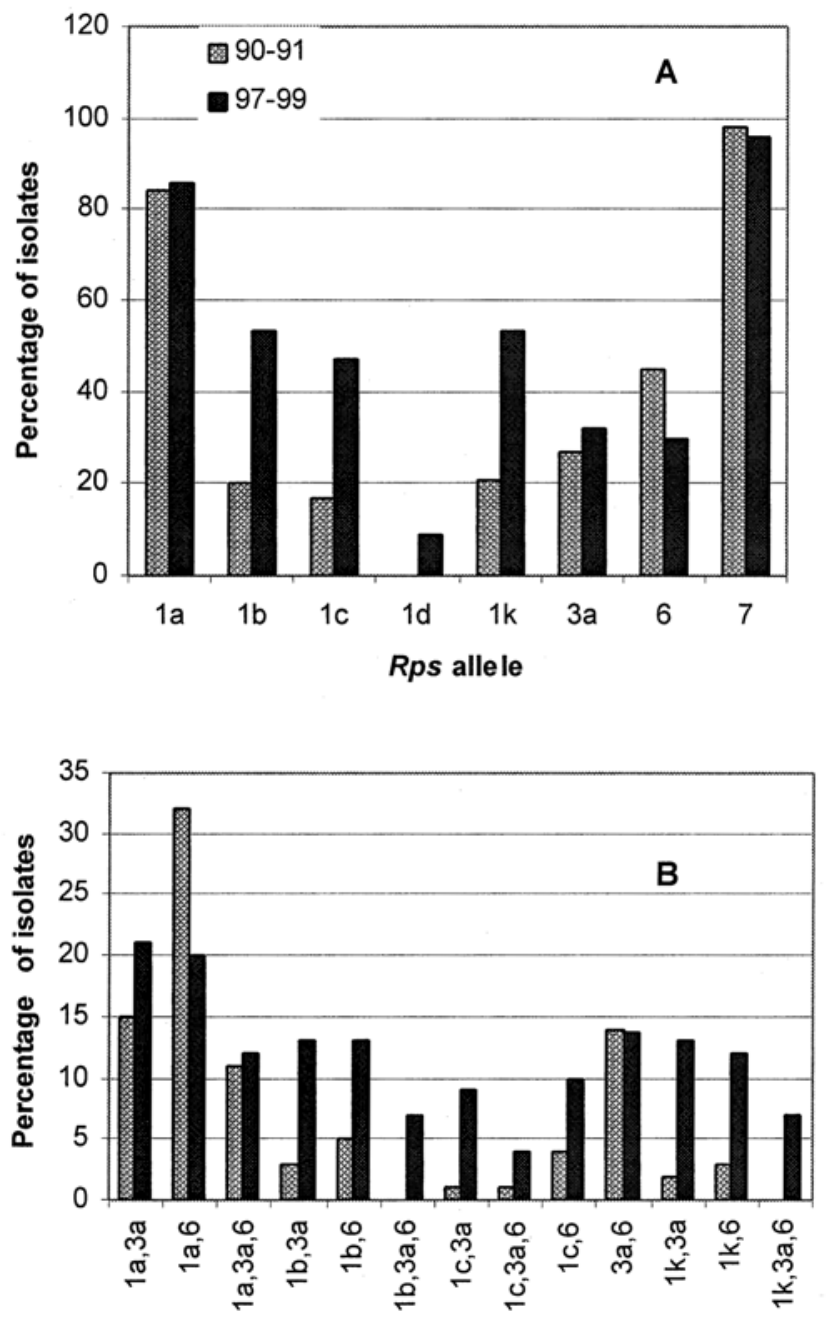

\section{Rps gene combinations}

Fig. 1. A, Comparison of Phytophthora sojae isolates collected from 57 fields during 1990/1991 and $1997 / 1999$ for changes in the number of isolates that had susceptible interactions with the Rps genes and $\mathbf{B}$, percentage of isolates that have susceptible interactions with 2- and 3-Rps gene combinations collected during 1990/1991 and 1997/1999. that were compatible on Rps $1 \mathrm{k}$ that were only recovered on the cultivar Resnik, and none of the isolates recovered on Sloan from these fields had virulence to Rps $1 \mathrm{k}$.

Comparison of current results to previous study. In the 1990/1991 survey, $P$. sojae was recovered from 48 of the 65 fields (30). We resampled 57 of the 65 fields during 1997/1999 and successfully isolated $P$. sojae from 56 fields. During the 1990/1991 survey, only 5 of the 57 had populations with virulence to $R p s 1 \mathrm{k}$, in comparison to 45 of the 57 fields in the current survey (Table 4). This was an increase from 8.7 to $78.9 \%$ of these fields with pathotypes with virulence to Rps $1 \mathrm{k}$ in northwestern Ohio.

During the 1990/1991 survey, only half of the isolates were evaluated on the Rps $1 \mathrm{~d}$ differential. Therefore, pathotypes, complexity, and mean pathogenic diversity were compared on only seven differentials. In the 1990/1991 survey, the mean complexity of the isolates on seven differentials (Rps1a, Rps 1b, Rps 1c, Rps 1k, Rps3a, Rps6, and Rps7) was 3.11 as calculated by the Habgood Spreadsheet (16). On these same seven differentials, the complexity was higher, 4.06, for the 1997/1999 survey. The number of recovered pathotypes was also higher; 55 in 1997/1999 compared with 48 in 1990/1991 (Table 5). The pathogenic diversity as measured by the Shannon index also increased from 2.71 to 3.28 over the 9 -year period on the seven differentials.

Intensive field sampling. The addition of $20 \mathrm{mg}$ of hymexazole limited the growth of Pythium spp. and greatly increased the efficiency of isolating $P$. sojae from these soils. Intensive sampling of the Wood and Sandusky county fields recovered 83 and $91 P$. sojae isolates, respectively, using the soybean cultivar Sloan as bait. Isolates recovered from the Wood County field represented 56 different pathotypes on 13 soybean differentials, whereas isolates from the Sandusky County field represented 54 different pathotypes (Table 5). While the numbers of pathotypes were similar, the complexity was greater for the Wood County field (7.01 compared with 5.67 for the Sandusky County field). The main difference between the two fields was a greater percentage of isolates with virulence to Rps 1b and Rps 1k in the Wood County field than in the Sandusky County field (Fig. 2). In contrast, there was a higher percentage of isolates with virulence to Rps1c in Sandusky County than in the Wood County field.

The pathogenic diversity for the statewide survey and the two intensively sampled fields were relatively high, although the Shannon index scores were lower, 3.61 and 3.80 for the Sandusky and Wood fields, compared with the statewide survey, which was 4.82 (Table 5). There was a greater number of pathotypes identified in the statewide survey (202) for the 82 fields 
in which $P$. sojae was recovered. This can be expected with the increased number of differentials used for this assessment and the increase in the number of isolates. Interestingly, the complexity of the populations was greatest for the Wood County location, not the statewide survey. This indicates that individual fields may be more diverse than the statewide population with regard to pathotype.

Management practices. Thirty-one of the 86 surveys were returned with information that could be used in the analysis. Only 14 of the surveys returned had completed cultivar information; therefore we could not compare development of new pathogen pathotypes based on gene deployment. However, information was complete with regard to the crops produced in a field (soybeans, corn, or wheat), tillage practices, soil type, and spacing of drain tiles. The correlation coefficients between the total number of differentials (representing eight Rps genes) with which isolates in a given field had a susceptible response and the presence of virulences to $R p s 1 \mathrm{k}$ and the variable used to represent tillage practices was significant $(P \leq 0.05)$. Because the variable for the presence of Rps 1k was binary (i.e., 0 or 1 [absent or present]), a generalized linear model with a logit link and binomial distribution then was fitted to the data (6). The number of differentials consists of counts (i.e., 1, 2, $3, \ldots 8)$, and it can be considered a Poisson variable; thus a generalized linear model with a linear link and Poisson distribution was fitted to the data (6). In both cases, there was a significant relationship with tillage based on a chi-square test of the change in deviance (D) for the model fit ( $P$ $<0.05$ ). For the presence of Rps $1 \mathrm{k}$, the chisquare statistic equaled 14.24, with 2 degrees of freedom $(P<0.001)$. Contrasts of

Table 4. Comparison of the presence of Phytophthora sojae and isolates that had a susceptible interaction with the Rps1k gene from fields sampled in 14 counties in northwest Ohio in 1990/1991 and in $1997 / 1999$

\begin{tabular}{|c|c|c|c|c|c|}
\hline \multirow[b]{2}{*}{ County } & \multirow[b]{2}{*}{$\begin{array}{c}\text { Fields } \\
\text { sampled }\end{array}$} & \multicolumn{2}{|c|}{$1990 / 1991$} & \multicolumn{2}{|c|}{ 1997/1999 } \\
\hline & & $\begin{array}{l}\text { Fields with } \\
\text { recovered } P \text {. sojae }\end{array}$ & $\begin{array}{l}\text { No. fields } \\
+R \operatorname{sp} 1 \mathrm{k}\end{array}$ & $\begin{array}{l}\text { No. fields with } \\
\text { recovered } P \text {. sojae }\end{array}$ & $\begin{array}{l}\text { No. fields } \\
+R \operatorname{Rp} 1 \mathrm{k}\end{array}$ \\
\hline Allen & 2 & 1 & 0 & 2 & 1 \\
\hline Crawford & 7 & 7 & 0 & 6 & 4 \\
\hline Defiance & 6 & 6 & 1 & 6 & 5 \\
\hline Hancock & 4 & 2 & 0 & 4 & 3 \\
\hline Hardin & 4 & 1 & 0 & 4 & 2 \\
\hline Huron & 1 & 1 & 0 & 1 & 1 \\
\hline Marion & 4 & 4 & 0 & 4 & 4 \\
\hline Ottawa & 5 & 4 & 3 & 5 & 4 \\
\hline Paulding & 4 & 3 & 1 & 4 & 4 \\
\hline Seneca & 6 & 6 & 0 & 6 & 4 \\
\hline VanWert & 6 & 3 & 0 & 6 & 6 \\
\hline Williams & 2 & 1 & 0 & 2 & 2 \\
\hline Wood & 3 & 0 & 0 & 3 & 3 \\
\hline Wyandot & 3 & 2 & 0 & 3 & 2 \\
\hline Total & 57 & 41 & 5 & 56 & 45 \\
\hline
\end{tabular}

Table 3. Octal code of the most common pathotypes of Phytophthora sojae recovered from 82 out of 86 fields sampled in Ohio during 1997 and 1999

\begin{tabular}{|c|c|c|c|c|c|c|c|}
\hline Pathotype $^{a}$ & Race $^{b}$ & Virulence formulae ${ }^{c}$ & $\begin{array}{l}\text { No. of } \\
\text { isolates }\end{array}$ & Pathotype & Race & Virulence formulae & $\begin{array}{c}\text { No. of } \\
\text { isolates }\end{array}$ \\
\hline 00000 & 0 & $r p s$ & 2 & 36551 & & $1 \mathrm{a}, 1 \mathrm{~b}, 1 \mathrm{k}, 2,3 \mathrm{a}, 3 \mathrm{c}, 4,6,7$ & 2 \\
\hline 00001 & 1 & 7 & 21 & 36571 & & $1 \mathrm{a}, 1 \mathrm{~b}, 1 \mathrm{k}, 2,3 \mathrm{a}, 3 \mathrm{c}, 4,5,6,7$ & 3 \\
\hline 00021 & & 5,7 & 3 & 36771 & & $1 \mathrm{a}, 1 \mathrm{~b}, 1 \mathrm{k}, 2,3 \mathrm{a}, 3 \mathrm{~b}, 3 \mathrm{c}, 4,5,6,7$ & 2 \\
\hline 04001 & & 2,7 & 4 & 50001 & 4 & $1 \mathrm{a}, 1 \mathrm{c}, 7$ & 15 \\
\hline 04021 & & $2,5,7$ & 3 & 50021 & & $1 \mathrm{a}, 1 \mathrm{c}, 5,7$ & 8 \\
\hline 04141 & & $2,3 a, 6,7$ & 2 & 52221 & & $1 \mathrm{a}, 1 \mathrm{c}, 1 \mathrm{k}, 3 \mathrm{~b}, 5,7$ & 2 \\
\hline 04561 & & $2,3 \mathrm{a}, 3 \mathrm{c}, 5,6,7$ & 2 & 54001 & & $1 \mathrm{a}, 1 \mathrm{c}, 2,7$ & 5 \\
\hline 04571 & & $2,3 \mathrm{a}, 3 \mathrm{c}, 4,5,6,7$ & 2 & 54021 & & $1 \mathrm{a}, 1 \mathrm{c}, 2,5,7$ & 5 \\
\hline 10001 & 3 & $1 \mathrm{a}, 7$ & 15 & 54051 & & $1 \mathrm{a}, 1 \mathrm{c}, 2,4,6,7$ & 2 \\
\hline 10021 & & $1 \mathrm{a}, 5,7$ & 2 & 54101 & & $1 \mathrm{a}, 1 \mathrm{c}, 2,3 \mathrm{a}, 7$ & 2 \\
\hline 10201 & & $1 \mathrm{a}, 3 \mathrm{~b}, 7$ & 2 & 72001 & 25 & $1 \mathrm{a}, 1 \mathrm{~b}, 1 \mathrm{c}, 1 \mathrm{k}, 7$ & 19 \\
\hline 14001 & & $1 \mathrm{a}, 2,7$ & 6 & 72021 & & $1 \mathrm{a}, 1 \mathrm{~b}, 1 \mathrm{c}, 1 \mathrm{k}, 5,7$ & 3 \\
\hline 14021 & & $1 \mathrm{a}, 2,5,7$ & 3 & 72101 & 20 & $1 \mathrm{a}, 1 \mathrm{~b}, 1 \mathrm{c}, 1 \mathrm{k}, 3 \mathrm{a}, 7$ & 3 \\
\hline 14121 & & $1 \mathrm{a}, 2,3 \mathrm{a}, 5,7$ & 3 & 72201 & & $1 \mathrm{a}, 1 \mathrm{~b}, 1 \mathrm{c}, 1 \mathrm{k}, 3 \mathrm{~b}, 7$ & 9 \\
\hline 14361 & & $1 \mathrm{a}, 2,3 \mathrm{a}, 3 \mathrm{c}, 7$ & 2 & 72221 & & $1 \mathrm{a}, 1 \mathrm{~b}, 1 \mathrm{c}, 1 \mathrm{k}, 3 \mathrm{~b}, 5,7$ & 3 \\
\hline 14371 & & $1 \mathrm{a}, 2,3 \mathrm{a}, 3 \mathrm{~b}, 4,5,6,7$ & 2 & 72301 & & $1 \mathrm{a}, 1 \mathrm{~b}, 1 \mathrm{c}, 1 \mathrm{k}, 3 \mathrm{a}, 3 \mathrm{~b}, 7$ & 2 \\
\hline 14401 & & $1 \mathrm{a}, 2,3 \mathrm{c}, 7$ & 2 & 74121 & & $1 \mathrm{a}, 1 \mathrm{~b}, 1 \mathrm{c}, 2,3 \mathrm{a}, 5,7$ & 2 \\
\hline 14571 & & $1 \mathrm{a}, 2,3 \mathrm{a}, 3 \mathrm{c}, 4,5,6,7$ & 7 & 76001 & & $1 \mathrm{a}, 1 \mathrm{~b}, 1 \mathrm{c}, 1 \mathrm{k}, 2,7$ & 6 \\
\hline 14771 & & $1 \mathrm{a}, 2,3 \mathrm{a}, 3 \mathrm{~b}, 3 \mathrm{c}, 4,5,6,7$ & 4 & 76021 & & $1 \mathrm{a}, 1 \mathrm{~b}, 1 \mathrm{c}, 1 \mathrm{k}, 2,5,7$ & 12 \\
\hline 22001 & & $1 \mathrm{~b}, 1 \mathrm{k}, 7$ & 2 & 76121 & & $1 \mathrm{a}, 1 \mathrm{~b}, 1 \mathrm{c}, 1 \mathrm{k}, 2,3 \mathrm{a}, 5,7$ & 2 \\
\hline 30001 & & $1 \mathrm{a}, 1 \mathrm{~b}, 7$ & 2 & 76201 & & $1 \mathrm{a}, 1 \mathrm{~b}, 1 \mathrm{c}, 1 \mathrm{k}, 2,3 \mathrm{~b}, 7$ & 3 \\
\hline 32001 & 28 & $1 \mathrm{a}, 1 \mathrm{~b}, 1 \mathrm{k}, 7$ & 12 & 76221 & & $1 \mathrm{a}, 1 \mathrm{~b}, 1 \mathrm{c}, 1 \mathrm{k}, 2,3 \mathrm{~b}, 5,7$ & 7 \\
\hline 32021 & & $1 \mathrm{a}, 1 \mathrm{~b}, 1 \mathrm{k}, 5,7$ & 6 & 76321 & & $1 \mathrm{a}, 1 \mathrm{~b}, 1 \mathrm{c}, 1 \mathrm{k}, 2,3 \mathrm{a}, 3 \mathrm{~b}, 5,7$ & 2 \\
\hline 32051 & & $1 \mathrm{a}, 1 \mathrm{~b}, 1 \mathrm{k}, 4,6,7$ & 2 & 76361 & & $1 \mathrm{a}, 1 \mathrm{~b}, 1 \mathrm{c}, 1 \mathrm{k}, 2,3 \mathrm{a}, 3 \mathrm{~b}, 5,6,7$ & 3 \\
\hline 32201 & & $1 \mathrm{a}, 1 \mathrm{~b}, 1 \mathrm{k}, 3 \mathrm{~b}, 7$ & 2 & 76451 & & $1 \mathrm{a}, 1 \mathrm{~b}, 1 \mathrm{c}, 1 \mathrm{k}, 2,3 \mathrm{c}, 4,6,7$ & 2 \\
\hline 34001 & & $1 \mathrm{a}, 1 \mathrm{~b}, 2,7$ & 2 & 76571 & & $1 \mathrm{a}, 1 \mathrm{~b}, 1 \mathrm{c}, 1 \mathrm{k}, 2,3 \mathrm{a}, 3 \mathrm{c}, 4,5,6,7$ & 4 \\
\hline 36001 & & $1 \mathrm{a}, 1 \mathrm{~b}, 1 \mathrm{k}, 2,7$ & 11 & 76761 & & $1 \mathrm{a}, 1 \mathrm{~b}, 1 \mathrm{c}, 1 \mathrm{k}, 2,3 \mathrm{a}, 3 \mathrm{~b}, 3 \mathrm{c}, 5,6,7$ & 2 \\
\hline 36021 & & $1 \mathrm{a}, 1 \mathrm{~b}, 1 \mathrm{k}, 2,5,7$ & 6 & 76771 & & $1 \mathrm{a}, 1 \mathrm{~b}, 1 \mathrm{c}, 1 \mathrm{k}, 2,3 \mathrm{a}, 3 \mathrm{~b}, 3 \mathrm{c}, 4,5,6,7$ & 6 \\
\hline 36201 & & $1 \mathrm{a}, 1 \mathrm{~b}, 1 \mathrm{k}, 2,3 \mathrm{~b}, 7$ & 2 & 77571 & & $1 \mathrm{a}, 1 \mathrm{~b}, 1 \mathrm{c}, 1 \mathrm{~d}, 1 \mathrm{k}, 2,3 \mathrm{a}, 3 \mathrm{c}, 4,5,6,7$ & 2 \\
\hline 36221 & & $1 \mathrm{a}, 1 \mathrm{~b}, 1 \mathrm{k}, 2,3 \mathrm{~b}, 5,7$ & 5 & 77761 & & $1 \mathrm{a}, 1 \mathrm{~b}, 1 \mathrm{c}, 1 \mathrm{~d}, 1 \mathrm{k}, 2,3 \mathrm{a}, 3 \mathrm{~b}, 3 \mathrm{c}, 5,6,7$ & 3 \\
\hline 36371 & & $1 \mathrm{a}, 1 \mathrm{~b}, 1 \mathrm{k}, 2,3 \mathrm{a}, 3 \mathrm{~b}, 4,5,6,7$ & 2 & 77771 & & $1 \mathrm{a}, 1 \mathrm{~b}, 1 \mathrm{c}, 1 \mathrm{~d}, 1 \mathrm{k}, 2,3 \mathrm{a}, 3 \mathrm{~b}, 3 \mathrm{c}, 4,5,6,7$ & 7 \\
\hline
\end{tabular}

a 0 indicates an incompatible reaction, and 1 indicates a compatible reaction on the differentials following inoculation. Octal digits were assigned as follows: $000=0,100=1,010=2,001=4,110=3,101=5,011=6$, and $111=7$. The octal digits in this system are sorted according to the number of virulences per triplet (16).

${ }^{\mathrm{b}}$ Race designations are given for those that are currently described in the literature. Race designations for the majority of races have only been designated using the following Rps genes: 1a, 1b, 1c, 1d, 1k, 3a, 6, and 7 (1,29).

${ }^{c}$ Pathotypes were determined by the hypocotyl injection technique on the following differentials: Williams (universal suscept), Harlon (Rps1a), Harosoy 13XX (Rps1b), Williams 79 (Rps1c), PI103091 (Rps1d), Williams 82 (Rps1k), L76-1988 (Rps2), L83-570 (Rps3), PRX 146-36 (Rps3b), PRX 145-48 (Rps3c), L85-2352 (Rps4), L85-3059 (Rps5), Harosoy 62XX (Rps6), and Harosoy (Rps7). 
the estimated parameters of the model, followed by the inverse-link function, can be used to predict the probability of Rps $1 \mathrm{k}$ being present for this model (6). Estimated probabilities (with standard errors in parentheses) were $0(-)$ for conventional tillage, $1(-)$ for reduced tillage, and $0.83(0.63)$ for no-tillage. When predicted probabilities equal 0 or 1 , standard errors are undefined. For counts of differentials with a susceptible response, the chi-square statistic equaled 12.41, with 2 degrees of freedom $(P<0.002)$. Contrasts of parameters for this model predict the expected number of differentials with a susceptible response. Estimated expected numbers (and standard errors) were 1.67 (0.74) for conventional tillage, $6.3(0.79)$ for reduced tillage, and 5.78 (0.57) for no-tillage. Model results for both cases indicated that the probability of $R p s 1 \mathrm{k}$ being present and the expected (mean) number of differentials with a susceptible response increased from conventional tillage to minimal tillage, but that there was no further increase from minimal tillage to no-tillage. The number of isolates recovered from a field was not significantly correlated with any of the other production practices, and generalized linear modeling was not pursued.

\section{DISCUSSION}

In Ohio, the most commonly deployed $R p s$ genes for $P$. sojae in commercial soybean cultivars have been Rps 1a, Rps 1b, $R p s 1 \mathrm{c}, R p s 1 \mathrm{k}, R p s 3 \mathrm{a}$, and Rps6. The results from this survey support the hypothesis that in Ohio, P. sojae is a highly variable pathogen with regard to pathotype and that there are a significant number of populations with individuals that can have a susceptible interaction with all of the known Rps genes. Schmitthenner et al. (29) had proposed that new phenotypes of $P$. sojae would increase in numbers and could potentially cause widespread damage in a short period of time. Ohio had dry summers during 1997 to 2000, but early spring rains resulted in 20 and $40 \%$ of the production acreage being replanted during 1997 and 2000, respectively, in several counties where $P$. sojae is endemic (A. E. Dorrance, unpublished data).

Limpert and Bartoš (24) outlined five key reasons for evaluating the pathogenic diversity of any plant pathogen: (i) to support cultivar selection by producers; (ii) to identify appropriate genes for breeding and deployment in resistant cultivars; (iii) to improve the understanding of the basic forces that drive pathogen evolution; (iv) to improve systems for predicting pathogen evolution; and (v) to improve strategies for the use of host resistance in time and space. Pathotyping by state or production region is critical to providing plant breeders with accurate regional data. Based on recent surveys, researchers in Michigan recommend incorporating Rps $1 \mathrm{~b}, R p s 1 \mathrm{k}$, $R p s 3 \mathrm{a}, R p s 3 \mathrm{~b}$, or Rps6 in soybean culti- vars, combined with other management procedures, to provide adequate control for $P$. sojae (18). In contrast, Indiana has proposed that gene combinations of Rps $1 \mathrm{k}$ or Rps 1c combined with Rps3a or Rps6 would provide control for $P$. sojae populations (5). These recommendations would not be suitable for Ohio, as there are already significant numbers of fields with populations that are capable of causing disease on soybeans with these stacked gene combinations. In addition, the proportion of the population and number of fields that have populations with virulence to Rps2, Rps3b, Rps3c, Rps4, and Rps5 also make these unlikely candidates for future cultivar development. Based on the virulence spectrum and complexity of $P$. sojae population in Ohio, single genes should continue to be used; however, partial resistance combined with other disease management practices also must be emphasized.

Table 5. Number of pathotypes (races), complexity, and mean pathogenic diversity of the Phytophthora sojae population collected in 1990/1991 and 1997/1999 on seven differentials from 65 fields in northwestern Ohio, in 1997/1999 from 82 locations, and from a field each in Wood and Sandusky counties in Ohio as measured by the Shannon index

\begin{tabular}{lcccccc}
\hline $\begin{array}{l}\text { P. sojae } \\
\text { collection }\end{array}$ & $\begin{array}{c}\text { No. of } \\
\text { fields }\end{array}$ & $\begin{array}{c}\text { No. of } \\
\text { isolates }\end{array}$ & $\begin{array}{c}\text { No. of } \\
\text { differentials }^{\mathbf{a}}\end{array}$ & $\begin{array}{c}\text { No. of } \\
\text { pathotypes }\end{array}$ & $\begin{array}{c}\text { Mean } \\
\text { complexity }^{\mathbf{b}}\end{array}$ & $\begin{array}{c}\text { Pathogenic } \\
\text { diversity }^{\mathbf{c}}\end{array}$ \\
\hline $1990 / 1991$ & 57 & 281 & 7 & 38 & 3.11 & 2.71 \\
$1997 / 1999$ & 57 & 312 & 7 & 55 & 4.06 & 3.28 \\
$1997 / 1999$ & 82 & 429 & 13 & 202 & 5.93 & 4.82 \\
Sandusky & 1 & 91 & 13 & 54 & 5.67 & 3.61 \\
Wood & 1 & 83 & 13 & 56 & 7.01 & 3.80 \\
\hline
\end{tabular}

a The pathotypes of the isolates were determined on the following differentials: Sloan (universal suscept), Harlon (Rps1a), Harosoy 13XX (Rps1b), Williams 79 (Rps1c), Williams 82 (Rps1k), PI 171442 (Rps3a), Altona (Rps6), and Harosoy (Rps7) during the 1990 and 1991 survey as previously reported by Schmitthenner et al. (29). Isolates baited from soil samples collected during 1997/1999 and 2000 were evaluated on the following differentials: Williams (universal suscept), Harlon (Rps1a), Harosoy 13XX (Rps1b), Williams 79 (Rps1c), PI103091 (Rps1d), Williams 82 (Rps1k), L76-1988 (Rps2), L83-570 (Rps3), PRX 146-36 (Rps3b), PRX 145-48 (Rps3c), L85-2352 (Rps4), L85-3059 (Rps5), Harosoy 62XX (Rps6), and Harosoy (Rps7).

${ }^{\mathrm{b}}$ Complexity indicates the number of Rps genes in the soybean differentials with which an isolate has a susceptible interaction.

${ }^{\mathrm{c}}$ Pathogenic diversity was measured by the Shannon index $(12,13)$ and calculated with the HaGiS spreadsheet program (16).

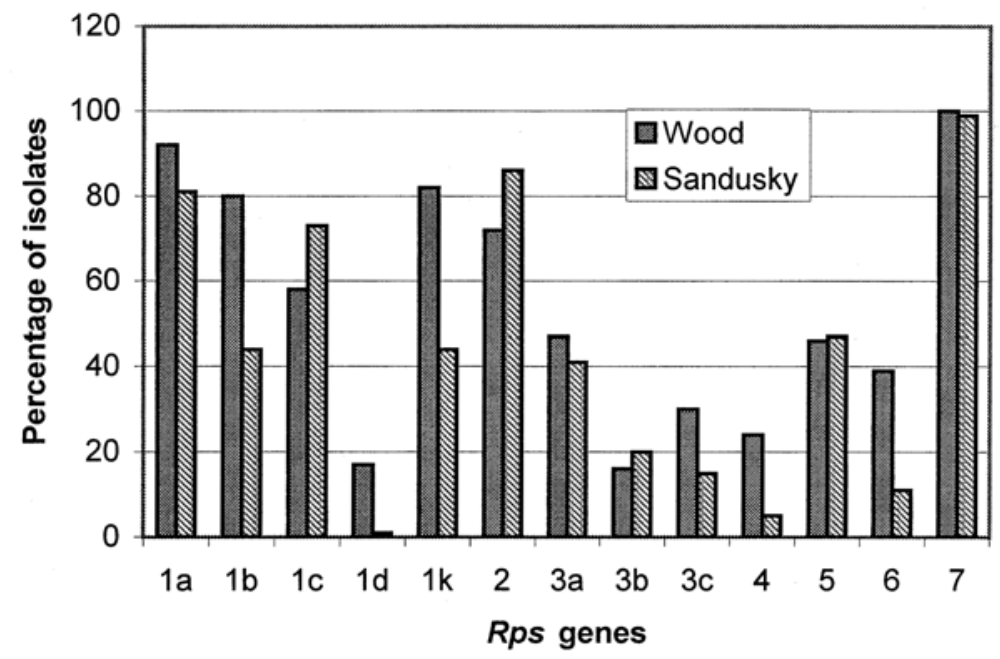

Fig. 2. Percentage of the Phytophthora sojae population that had a susceptible interaction with Rps genes collected from one field each in Wood and Sandusky counties, OH. 
genes. A greater number of isolates, 221, were recovered from these soils when the soybean cultivar Sloan was used as bait compared with Resnik. Resnik has the Rps $1 \mathrm{k}$ gene, and only $53 \%$ of the total population of isolates could cause disease on cultivars with this gene. All of the isolates recovered with Resnik were pathogenic on soybean, and $87 \%$ had compatible interactions with the Rps $1 \mathrm{k}$ differential as determined with the hypocotyl inoculation (29). This is in contrast to the previous survey (29), in which 36 isolates were baited with the soybean cultivar Amcor89 (Rps 1k) but few had a compatible interaction with the Rps $1 \mathrm{k}$ differential when tested with the hypocotyl inoculation technique. Schmitthenner et al. (29) also reported that the soybean differential (Rps1a) inoculated with a mixture of races as low as 1:9 (vir:avir) had a susceptible reaction. Isolates recovered from fields are known to be quite variable in their reactions. There is the possibility that as the population evaluated during 1990 to 1991 was undergoing change, and individuals with virulence to $R p s 1 \mathrm{k}$ were in a low proportion to the total population. The results from this survey would indicate that virulence to $R p s 1 \mathrm{k}$ is now predominant in the fields where it exists. More research is needed to refine this technique as well as to determine if this will be a useful tool to predict gene performance.

A major concern arising from this study, as well as from recent reports from Michigan, is the growing number of isolates with complex pathotypes. Approximately 20\% of the isolates surveyed in Michigan had virulence to 10 or more Rps genes (18). This poses two distinct problems: (i) maintenance of simple pathotypes required for screening germ plasm, and (ii) limited potential for recycling formerly deployed Rps genes. P. sojae isolates with virulence to 1 or 2 Rps genes simplify screening efforts for Rps gene identification and verification. Preservation of these less complex types will be essential to assist breeding programs in the future. Recycling of host resistance genes is dependent on the pathogen's loss of virulence to Rps genes reaching undetectable levels in the pathogen population over time. The current results indicate that these populations are maintaining virulence to Rps genes in the population, and redeploying resistance genes does not appear to be an option.

Unnecessary virulences may increase, remain the same, or decrease in a pathogen population (3). This is dependent on whether or not virulence to a specific $R p s$ gene(s) is closely associated or tightly linked to other favorable traits for survival of the pathogen. In addition, maintenance of virulence to resistance genes in a population is reported to be strong in pathogens, such as Erysiphe graminis f. sp. hordei, that reproduce clonally (3). How long virulences to $P$. sojae may survive in a popula- tion and if recycling of Rps genes may be an option in the future are unknown, primarily because the degree of clonality or outcrossing that occurs within a single field population of $P$. sojae remains unknown $(9,34)$. Pathotypes are often not indicative of the degree to which a pathogen population exists as a clone. Analysis of these populations is underway to determine the level of molecular diversity.

The results from the crop management survey indicate that no-till or conservation tillage systems may be having an impact on the development of complex populations of $P$. sojae, and many of these fields have populations with susceptible interactions with all of the known Rps genes. The recovery of $P$. sojae from fields in four of five states was reported to be greater from conservation tillage fields than from conventional tillage fields (35). However, further analysis of this same data set revealed that soil texture may impact this relationship (37). In fine-textured soils, there was a difference in detection of $P$. sojae between tillage systems (37). P. sojae is more readily detected near the soil surface in no-till fields when compared with conventional fields (36). Oospores are formed in root and stem tissues and thus serve as a ready reservoir of inoculum near the soil surface in conservation tillage systems. The oospores that are produced in any given year represent the most successful pathotypes within the pathogen population. Under a reduced tillage system, these successful pathotypes are maintained near the soil surface, thus increasing a given pathotypes chances of survival through pathogenesis. Pfender et al. (26) determined that migration of zoospores of $P$. megasperma was limited (approximately $24 \mathrm{~mm}$ ) in a silt loam soil compared with $65 \mathrm{~mm}$ in a sandy loam soil.

We conclude from this study that more fields in Ohio now have detectable populations of $P$. sojae that are capable of causing disease on cultivars with the Rps $1 \mathrm{k}$ gene than nearly a decade ago. In a previous study, soybean cultivars planted without partial resistance sustained high yield losses when conditions were very conducive for Phytophthora root rot (30). This current study also indicates that we may begin to see widespread economic losses in this state, typical of earlier population shifts, if cultivars with these Rps genes are planted without high levels of partial resistance. The driving forces of pathogen evolution are still unknown, but further molecular analysis of these collections may provide information on the mechanisms that support population change. Baiting soil samples with a cultivar with a specific Rps gene may be useful in detecting population shifts. However, further analysis and refinement of this strategy as a disease management tool for prediction of Rps gene performance are needed. Host resistance continues to be the most economical and efficient tool for managing this soilborne pathogen. As the pathogen population continues to change, the need to discover novel and effective resistance genes becomes imperative.

\section{ACKNOWLEDGMENTS}

We thank P. E. Lipps and L. V. Madden for critically reviewing this manuscript. A special thank you to $\mathrm{L}$. V. Madden for assistance with the statistical analysis. Salaries and research support provided by state and federal funds appropriated to the Ohio Agricultural Research and Development Center, Ohio State University. This research was sponsored by Ohio's soybean producers' check-off dollars through the Ohio Soybean Council.

\section{LITERATURE CITED}

1. Abney, T. S., Melgar, J. C., Richards, T. L., Scott, D. H., Grogan, J., and Young, J. 1997. New races of Phytophthora sojae with Rps1-d virulence. Plant Dis. 81:653-655.

2. Anderson, T. R. 1986. Plant losses and yield responses to monoculture of soybean cultivars susceptible, tolerant, and resistant to Phytophthora megasperma f. sp. glycinea. Plant Dis. 70:468-471.

3. Brown, J. K. M. 1995. Pathogens' responses to the management of disease resistance genes. Adv. Plant Pathol. 11:75-102.

4. Canaday, C. H., and Schmitthenner, A. F. 1982. Isolating Phytophthora megasperma f. sp. glycinea from soil with a baiting method that minimizes Pythium contamination. Soil Biol. Biochem. 14:67-68.

5. Cochran, A. J., and Abney, T. S. 1999. Rps gene combinations needed to control diverse pathotypes of Phytophthora sojae. (Abstr.) Phytopathology 89:S104.

6. Dobson, A. 1990. An Introduction to Generalized Linear Models. Chapman \& Hall, London.

7. Erwin, D. C., and Ribeiro, O. K. 1996. Phytophthora Diseases Worldwide. American Phytopathological Society, St. Paul, MN.

8. Flor, H. H. 1955. Host parasite interaction in flax rust-Its genetics and other implications. Phytopathology 45:680-685.

9. Förster, H., Tyler, B., and Coffey, M. 1994 Phytophthora sojae races have arisen by clonal evolution and by rare outcrosses. Mol. Plant-Microbe Interact. 7:780-791.

10. Gilmour, J. 1973. Octal notation for designating physiologic races of plant pathogens. Nature 242:620.

11. Goodwin, S. B., Allard, R. W., and Webster, R. K. 1990. A nomenclature for Rhynchosporium secalis pathotypes. Phytopathology 80:1330-1336.

12. Goodwin, S. B., Sujkowski, L. S., and Fry, W. E. 1995. Rapid evolution of pathogenicity within clonal lineages of the potato late blight disease fungus. Phytopathology 85:669-676.

13. Groth, J. V., and Roelfs, A. P. 1987. The concept and measurement of phenotypic diversity in Puccinia graminis on wheat. Phytopathology 77:1395-1399.

14. Haas, J. H., and Buzzell, R. I. 1976. New races 5 and 6 of Phytophthora megasperma var. sojae and differential reactions of soybean cultivars for races 1 to 6 . Phytopathology $66: 1361-1362$.

15. Henry, R. N., and Kirkpatrick, T. L. 1995. Two new races of Phytophthora sojae, causal agent of Phytophthora root and stem rot of soybean, identified from Arkansas soybean fields. Plant Dis. 79:1074.

16. Herrmann, A., Löwer, C. F., and Schachtel, G. A. 1999. A new tool for entry and analysis of virulence data for plant pathogens. Plant Pathol. 48:154-158.

17. Jeffers, S. N., and Martin, S. B. 1986. Com- 
parison of two media selective for Phytophthora and Pythium species. Plant Dis. 70:1038-1043.

18. Kaitany, R. C., Hart, L. P., and Safir, G. R. 2001. Virulence composition of Phytophthora sojae in Michigan. Plant Dis. 85:1103-1106.

19. Kauffmann, M. J., and Gerdemann, J. W. 1958. Root and stem rot of soybean caused by Phytophthora sojae n. sp. Phytopathology 48:201-208.

20. Kilen, T. C., Hartwig, E. E., and Keeling, B. L. 1974. Inheritance of a second major gene for resistance to Phytophthora rot in soybeans. Crop Sci. 14:260-262.

21. Kurle, J. E., and El Araby, E. M. 2001. Changing composition of Phytophthora sojae races in Minnesota soils. (Abstr.) Phytopathology 91:S51.

22. Laviolette, F. A., and Athow, K. L. 1977. Three new physiologic races of Phytophthora megasperma var. sojae. Phytopathology 67:267-268.

23. Leitz, R. A., Hartman, G. L., Pedersen, W. L., and Nickell, C. D. 2000. Races of Phytophthora sojae on soybean in Illinois. Plant Dis. 84:487.

24. Limpert, E., and Bartoš, P. 1997. Analysis of pathogen virulence as decision support for breeding and cultivar choice. Pages 401-424 in: Resistance of Crop Plants Against Fungi. H. Hartleb, R. Heitefuss, and H. H. Hoppe, eds. Gustav Fisher, Stuttgart.

25. Morgan, F. L., and Hartwig, E. E. 1965.
Physiologic specialization in Phytophthora megasperma var. sojae. Phytopathology 55:1277-1279.

26. Pfender, W. F., Hine, R. B., and Stanghellini, M. E. 1977. Production of sporangia and release of zoospores by Phytophthora megasperma in soil. Phytopathology 67:657663.

27. Ryley, M. J., Obst, N. R., Irwin, J. A. G., and Drenth, A. 1998. Changes in the racial composition of Phytophthora sojae in Australia between 1979 and 1996. Plant Dis. 82:10481054.

28. Schmitthenner, A. F. 1985. Problems and progress in control of Phytophthora root rot of soybean. Plant Dis. 69:362-368.

29. Schmitthenner, A. F., Hobe, M., and Bhat, R. G. 1994. Phytophthora sojae races in Ohio over a 10-year interval. Plant Dis. 78:269276.

30. Schmitthenner, A. F., and Van Doren, D. M., Jr. 1985. Integrated control of root rot of soybean caused by Phytophthora megasperma f. sp. glycinea. Pages 263-266 in: Ecology and Management of Soilborne Plant Pathogens. C. A. Parker, A. D. Rovira, K. J. Moore, P. T. W. Wong, and J. F. Kollmorgen, eds. American Phytopathological Society, St. Paul, MN.

31. Schwenk, F. W., and Sim, T. 1974. Race 4 of Phytophthora megasperma var. sojae from soybeans proposed. Plant Dis. Rep. 58:353354
32. Wagner, R. E., and Wilkinson, H. T. 1992. A new physiological race of Phytophthora sojae on soybean. Plant Dis. 76:212.

33. Ward, E. W. B. 1990. The interaction of soya beans with Phytophthora megasperma f. sp. glycinea: Pathogenicity. Pages 311-327 in: Biological Control of Soil-borne Plant Pathogens. D. Hornby, ed. CAB International, Wallingford, England.

34. Whisson, S. C., Drenth, A., MacLean, D. J. and Irwin, J. A. G. 1994. Evidence for outcrossing in Phytophthora sojae and linkage of a DNA marker to two avirulence genes. Curr Genet. 27:77-82.

35. Workneh, F., Tylka, G. L., Yang, X. B Faghihi, J., and Ferris, J. M. 1999. Regional assessment of soybean brown stem rot, Phytophthora sojae, and Heterodera glycines using area-frame sampling: Prevalence and effects of tillage. Phytopathology 89:204-211.

36. Workneh, F., Yang, X. B., and Tylka, G. L. 1998. Effect of tillage practices on vertical distribution of Phytophthora sojae. Plant Dis. 82:1258-1263.

37. Workneh, F., Yang, X. B., and Tylka, G. L. 1999. Soybean brown stem rot, Phytophthora sojae, and Heterodera glycines affected by soil texture and tillage relations. Phytopathology 89:844-850.

38. Yang, X. B., Ruff, R. L., Meng, X. Q., and Workneh, F. 1996. Races of Phytophthora sojae in Iowa soybean fields. Plant Dis. 80:1418-1420. 